\title{
Analisis yuridis pengelompokan wilayah pada notaris berkaitan norma perhitungan penghasilan neto terkait pejabat umum
}

\author{
Amanda Puteri Rachmatullah"1, Tunggul Anshari SN², Diah Aju Wisnu W'
}

${ }^{1}$ Amanda Puteri Rachmatullah; Magister Kenotariatan Universitas Brawijaya; Jalan MT. Haryono 169 Malang; 65145; Jawa Timur; Indonesia.

${ }^{2}$ Tunggul Anshari SN; Fakultas Hukum Universitas Brawijaya; Jalan MT. Haryono 169 Malang; 65145; Jawa Timur; Indonesia.

${ }^{3}$ Diah Aju Wisnu W; Fakultas Hukum Universitas Merdeka Malang; Jalan Terusan Dieng 62-64 Malang; 65145; Jawa Timur; Indonesia.

\section{A RT I CLEINFO}

Article history:

Received 2021-01-25

Received in revised form

2021-04-14

Accepted 2021-08-01

Kata kunci:

NPPN; Pengelompokan Wilayah; Notaris.

Keywords:

NPPN; Regional Grouping; Notary.

DOI: https://doi.org/10.26905/

idjch.v12i2.5811.

How to cite item:

Rachmatullah, A. P., Anshari, T., Wisnuwardhani, D. A. (2021). Analisis yuridis pengelompokan wilayah pada notaris berkaitan norma perhitungan penghasilan neto terkait pejabat umum. Jurnal Cakrawala Hukum, 12(2), 129-138. doi:10.26905/idjch.v12i2. 5811.

\begin{abstract}
Abstrak
Berbagai sebab yang melatarbelakangi terjadinya tindak pidana ini diduga berawal dari ketidakpuasan yang muncul dari diri si pelaku. Ketidakpuasan terhadap ekonomi, penegakan hukum, terjadinya kesenjangan sosial bahkan ketidakpuasan terhadap ideology, menjadi permasalahan yang harus terselesaikan. Ketidakpuasan tersebut didorong dengan rendahnya pemahaman akan ilmu dan pengetahuan, sehingga seseorang atau kelompok orang cenderung akan mengambil jalan pintas dengan melakukan suatu tindak pidana, seperti terorisme. Keterlibatan berbagai pihak menjadi hal penting sebagai salah satu tolok ukur keberhasilan pencegahan tindak pidana terorisme ini, diantaranya keterlibatan organisasi masyarakat seperti Majelis Ulama Indonesia sebagai suatu organisasi pembinaan umat dari terjadinya kesalahan dalam memahami perihal agama. Terorisme adalah suatu tindakan yang didasari sistem nilai dan cara pandang dunia, sehingga untuk memahaminya diperlukan suatu kerangka dan metodologi pemikiran yang biasa digunakan dalam tradisi filsafat. Metode penelitian yang digunakan dalam penelitian ini adalah Yuridis-Sosiologis dengan pendekatan empiris yang dikaji secara filosofis untuk menemukan suatu konsep pencegahan tindak pidana terorisme melalui pendekatan lunak.
\end{abstract}

\section{Abstract}

The various reasons behind the occurrence of this crime are thought to have originated from dissatisfaction with the perpetrator. Dissatisfaction with the economy, law enforcement, social inequality and even dissatisfaction with ideology, are problems that must be resolved. This dissatisfaction is driven by a low understanding of

\footnotetext{
* Amanda Puteri Rachmatullah.

E-mail address: amandaputeri3@gmail.com.

C2021 Jurnal Cakrawala Hukum - University of Merdeka Malang.
} 


\section{Jurnal Cakrawala Hukum, Volume 12 No. 2 Agustus 2021 \\ ISSN PRINT 2356-4962 ISSN ONLINE 2598-6538}

science and knowledge, so that a person or group of people tends to take shortcuts by committing a crime, such as terrorism. The involvement of various parties is important as one of the benchmarks for the success of preventing this crime of terrorism, including the involvement of community organizations such as the Indonesian Ulama Council as an organization to foster people from errors in understanding religious matters. Terrorism is an action that is based on a value system and world view, so that understanding it requires a framework and methodology of thought commonly used in the philosophical tradition. The research method used in this research is juridical-sociological with an empirical approach that is studied philosophically to find a concept of preventing the crime of terrorism through a soft approach.

\section{Latar Belakang}

Notàris adalah pejabat umum yang berhak untuk mengeluarkan akta otentik dan wewenang lainnya yang diatur pada Undang-Undang Republik Indonesia Nomor 2 Tahun 2014 Tentang Perubahan Atas Undang-Undang Republik Indonesia Nomor 30 Tahun 2004 Tentang Jabatan Notaris (UUJN) (Juniresta, 2021). Notaris adalah suatu jabatan yang bertugas menjalankan beberapa fungsi Negara di ranah hukum perdata dengan kewenangan untuk membuat akta otentik, yang berdasar kepada keterangan pihak-pihak yang bersangkutan untuk menghadap kepada notaris Notaris yang berada di Indonesia selain berkewajiban untuk melaksanakan kewajibannya sebagai pejabat umum, ia juga tetap berkewajiban untuk memenuhi kewajibannya sebagai warga negara Indonesia yang salah satu kewajiban tersebut adalah kewajiban perpajakan. Sebagaimana tertuang dalam Undang-Undang Nomor 7 Tahun 1983 Tentang Pajak Penghasilan sebagaimana diubah terakhir kali dengan Undang-Undang Nomor 36 Tahun 2008 tentang perubahan keempat atas Undang-Undang Nomor 7 Tahun 1983 Tentang Pajak Penghasilan (selanjutnya disebut UU PPh) mendefinisikan Pajak Penghasilan sebagai pajak yang dikenakan kepada orang pribadi atau badan atas penghasilan yang diterima atau diperoleh dalam suatu Tahun Pajak. Penghasilan dalam definisi tersebut dapat diartikan sebagai setiap tambahan kemampuan ekonomis yang diterima atau diperoleh Wajib Pajak baik yang berasal baik dari Indonesia maupun dari luar Indonesia yang dapat dipakai untuk konsumsi atau untuk menambah kekayaan Wajib Pajak yang bersangkutan dengan nama dan dalam bentuk apapun. Dengan demikian, dapat diketahui bahwa penghasilan tersebut dapat berupa keuntungan usaha, gaji, honorarium, hadiah, dan lain sebagainya. Pajak penghasilan merupakan salah satu jenis pajak langsung dimana pihak yang berwenang untuk memungut serta mengaturnya adalah Direktorat Jenderal Pajak dibawah Kementerian Keuangan Republik Indonesia.

Berdasarkan penjelasan Pasal 4 ayat (1) UU PPh, Notaris merupakan salah satu wajib pajak orang pribadi yang melakukan kegiatan usaha atau pekerjaan bebas. Sehubungan dengan tugas jabatan Notaris, penghasilan yang di dapatkan oleh Notaris antara lain dapat berupa honorarium dan uang jasa hukum yang diberikan sesuai dengan kewenangan Notaris sebagaimana yang diatur dalam UUJN. dalam peraturan pasal 28 ayat (1) Undang-Undang Nomor 6 Tahun 1983 tentang Ketentuan Umum dan Tata Cara Perpajakan sebagaimana diubah terakhir kali dengan UndangUndang Nomor 16 Tahun 2009 tentang perubahan keempat atas Undang-Undang Nomor 6 Tahun 1983 tentang Ketentuan Umum dan Tata Cara Perpajakan (selanjutnya disebut UU KUP) mewa- 
jibkan untuk menyelenggarakan pembukuan bagi wajib pajak orang pribadi yang melakukan kegiatan usaha atau pekerjaan bebas. Sehingga menurut penjelasan pasal 28 ayat (1) UU KUP oleh karena Notaris termasuk wajib pajak orang pribadi yang melakukan kegiatan usaha atau pekerjaan bebas maka memilik kewajiban untuk melaksanakan pembukuan. Namun pemerintah kemudian menyadari bahwa kewajiban menyelenggarakan pembukuan sebagaimana mestinya tidak dapat dilaksanakan oleh semua orang termasuk Notaris. Oleh karena itu pemerintah mengeluarkan aturan Norma Penghitungan Penghasilan Neto (NPPN) sebagai alternatif perhitungan penghasilan neto selama wajib pajak tersebut memenuhi persyaratan sebagaimana tercantum dalam peraturan perundang-undangan lainnya.

Aturan Pasal 4 ayat (1) PER DIRJEN PAJAK Nomor 17/PJ/2015 tentang NPPN kemudian menyebutkan bahwa Daftar Persentase Norma Penghitungan Penghasilan Neto dikelompokkan menurut wilayah sebagai berikut: (a). 10 (sepuluh) ibukota propinsi yaitu Medan, Palembang, Jakarta, Bandung, Semarang, Surabaya, Denpasar, Manado, Makassar dan Pontianak; (b). Ibukota propinsi lainnya; dan (c). Daerah lainnya."

Berdasarkan kutipan pasal tersebut disimpulkan bahwa untuk menentukan besaran persentase NPPN yang akan digunakan untuk menghitung penghasilan neto seorang wajib pajak, maka dilihat terlebih dahulu wilayah atau domisili kerja dari wajib pajak yang bersangkutan. Dalam hal ini, jika dikaitkan dengan Notaris, maka besaran persentase NPPN yang akan digunakan oleh Notaris didasarkan pada wilayah atau domisili kerja Notaris yang bersangkutan. Apabila melihat dalam daftar lampiran I PER DIRJEN PAJAK Nomor 17/PJ/2015 diketahui bahwa terdapat selisih persentase NPPN untuk jasa Notaris berdasarkan wilayah domisili kerjanya. Adapun persentase tersebut antara lain: a) Untuk kelompok wilayah A sebesar 51\%, b) Untuk kelompok wilayah B sebesar
$50 \%$ dan c) Untuk kelompok wilayah C sebesar $50 \%$.

PER DIRJEN PAJAK Nomor 17/PJ/2015 tidak dijelaskan lebih lanjut mengapa besaran persentase NPPN tersebut terbagi berdasarkan wilayah atau domisili kerja wajib pajak dalam hal ini Notaris. Selain itu, pada Peraturan Menteri Hukum dan Hak Asasi Manusia Republik Indonesia Nomor 27 Tahun 2016 tentang Formasi Jabatan Notaris dan Penentuan Kategori Daerah (Selanjutnya disebut PERMENKUMHAM Nomor 27/ 2016) kemudian juga mengatur mengenai adanya pengelompokan tempat kedudukan Notaris berdasarkan kriteria formasi Jabatan Notaris. Formasi Jabatan Notaris merupakan penentuan jumlah Notaris yang dibutuhkan pada suatu Kabupaten atau Kota yang mana formasi jabatan ini merupakan kriteria dasar untuk pengelompokan tempat kedudukan Notaris yang biasa disebut dengan Kategori Daerah. Atas dasar penentuan formasi jabatan Notaris, pada pasal 7 ayat (2) PERMENKUMHAM Nomor 27/2016 kemudian terdapat pembagian kategori daerah untuk formasi jabatan Notaris yang terdiri atas Kategori A, Kategori B, Kategori C dan Kategori D.

Berdasarkan latar belakang diatas, penelitian ini meneliti lebih lanjut mengenai pengelompokan NPPN berdasarkan wilayah yang menyebabkan perbedaan presentase bagi Notaris menggunakan metode pencatatan dan menggunakan perhitungan pajaknya dengan NPPN. Selain itu, juga akan meneliti bagaimana korelasi pembagian wilayah antara pembagian wilayah domisili kerja Notaris berdasarkan PER DIRJEN PAJAK Nomor 17/PJ/2015 dengan pembagian wilayah formasi jabatan Notaris berdasarkan PERMENKUMHAM Nomor $27 / 2016$.

\section{Metode}

Metode Penelitian dalam penulisan artikel ini adalah metode penelitian normatif. Metode 


\section{Jurnal Cakrawala Hukum, Volume 12 No. 2 Agustus 2021}

ISSN PRINT 2356-4962 ISSN ONLINE 2598-6538

penelitian normative mengutip pendapat Terry Hutchinson yang dikutip oleh Peter Mahmud adalah penelitian sistematis untuk menjelaskan secara sistematis aturan suatu kategori hukum tertentu serta mengalisis hubungan antara peraturan atas kesulitan serta memprediksi pembangunan hukum ke depan (Marzuki, 2011). Dalam metode penelitian normative ini digunakan metode pendekatan peraturan perundang-undangan (statute approach) dan pendekatan teoritis (theoretical approach).

\section{Pembahasan}

\subsection{Dasar pertimbangan hukum (ratio logis) pengelompokan wilayah pada pasal 4 ayat (1) PER DIRJEN PAJAK Nomor 17/PJ/ 2015}

Dalam melaksanakan tugas jabatan dan kewenangannya, Notaris berpedoman dan tunduk pada aturan UUJN dan kode etik Notaris dan seorang Notaris dapat menolak pembuatan akta jika ketentuan yang terkandung di dalamnya melanggar ketertiban umum, kesusilaan, dan peraturan perundang-undangan (Pratiwi, 2020). Namun sebagai warga negara Notaris juga tetap harus tunduk pada hukum positif yang berlaku di Indonesia. Salah satunya adalah dengan memenuhi kewajiban perpajakannya sebagaimana diatur pada peraturan perpajakan Indonesia. Notaris merupakan salah satu wajib pajak orang pribadi yang melakukan kegiatan usaha atau pekerjaan bebas. Hal ini selaras dengan pengertian pekerjaan bebas dalam Pasal 1 angka 24 UU KUP dimana suatu pekerjaan bebas merupakan pekerjaan yang dilakukan berdasarkan keahlian khusus dan tidak terikat suatu hubungan kerja. Hubungannya dengan keahlian khusus dengan mengikuti suatu pendidikan tertentu, berdasarkan persyaratan diangkatnya seseorang menjadi Notaris sebagaimana disebutkan dalam pasal 3 ayat (1) UUJN dan Pasal 2 ayat (2) dan ayat (3) PERMENKUMHAM Nomor 19/2019 diketahui bahwa salah satu persyaratan yang harus dipenuhi untuk menjadi seorang Notaris yaitu calon Notaris yang bersangkutan harus memiliki keahlian khusus yang didapatkan dari pendidikan formal berupa dimilikinya ijazah sarjana hukum serta telah lulus jenjang strata dua kenotariatan.

Sebagaimana telah dijelaskan pada latar belakang diatas, Notaris sebagai wajib pajak orang pribadi yang melakukan pekerjaan bebas diwajibkan untuk menyelenggarakan pembukukuan. Tetapi Notaris diperbolehkan hanya menyelenggarakan pencatatan dan menggunakan NPPN dalam pemenuhan kewajiban perpajakan, jika Notaris tersebut telah memenuhi persyaratan antara lain: 1) Notaris yang bersangkutan dalam 1 (satu) tahun pajak memiliki peredaran bruto kurang dari Rp.4.800.000.000,(empat milyar delapan ratus juta ribu rupiah), 2) Wajib memberitahukan terlebih dahulu mengenai penggunaan NPPN tersebut kepada Direktur Jenderal Pajak melalui KPP Pratama dimana Notaris tersebut terdaftar paling lama 3 (tiga) bulan sejak awal Tahun Pajak yang bersangkutan, 3) Tetap menyelenggarakan pencatatan sebagaimana dimaksud dalam UU KUP.

UU PPh memperluas pengertian penghasilan yang diperoleh wajib pajak (dalam hal ini termasuk juga Notaris) menggunakan asas world wide income atau penghasilan dalam arti luas, sehingga semua kegiatan yang menghasilkan pendapatan merupakan objek PPh. Umumnya penghasilan seorang Notaris berupa honorarium dan uang jasa hukum yang diberikan sesuai dengan kewenangan Notaris sebagaimana yang diatur dalam UUJN serta peraturan perundang-undangan yang berlaku lainnya (Aruan, 2020). Tetapi apabila melihat kembali definisi penghasilan menurut UU PPh, maka penghasilan Notaris tidak hanya terbatas pada honorarium yang diterimanya dalam melaksanakan tugas jabatan dan kewenangannya.

Sebagaimana yang kita ketahui, Naskah Akademik merupakan dokumen yang berisi latar belakang dirancangnya suatu peraturan perundangundangan. Selain dalam naskah akademik, pada 
umumnya suatu peraturan terdapat bab penjelasan dimana dalam bab tersebut menjelaskan makna atau arti pasal demi pasal pada peraturan perundang-undangan tersebut. Namun pada Lampiran II UU Nomor 12/2011 tentang Teknik Penyusunan Peraturan Peundang-undangan Bab I Huruf E dijelaskan bahwa tidak ada kewajiban untuk melampirkan bab penjelasan namun dapat diberi penjelasan jika diperlukan untuk peraturan perundang-undangan dibawah undang-undang (selain Peraturan Daerah Provinsi dan Kabupaten/ Kota). Sehingga baik Peraturan Menteri Keuangan Republik Indonesia dan Peraturan Direktur Jenderal Pajak tidak ada kewajiban diberikan penjelasan pada setiap peraturan atau keputusan yang diterbitkannya. Oleh karena itu berdasarkan ketentuan UU Nomor 12/2011, naskah akademik rancangan UU PPh beserta penjelasannya dikarenakan PER DIRJEN PAJAK Nomor 17/PJ/2015 tidak memiliki naskah akademik maupun bab penjelasan karena tidak adanya keharusan atau kewajiban untuk membuat dokumen tersebut sebagaimana penjelasan diatas.

Secara umum, NPPN pertama kali diatur dalam Undang-Undang Nomor 7 Tahun 1983 tentang Pajak Penghasilan. Pada undang-undang ini, istilah NPPN masih menggunakan Norma Penghitungan dimana Norma penghitungan ini diatur pada pasal 14 ayat (1) hingga ayat (7). Norma Penghitungan merupakan suatu pedoman yang dapat dipakai sebagai cara untuk menentukan peredaran bruto atau penerimaan bruto dan yang pada akhirnya untuk menentukan penghasilan netto yang dibuat oleh Pemerintah secara yang terbuka dan adil, disamping perlunya pembinaan agar supaya wajib pajak kemudian dapat dan mampu menyelenggarakan pembukuan di kemudian hari. Penggunaan Norma Perhitungan bagi wajib pajak hanya dipergunakan sebagai alternatif penghitungan atau penghasilan bersih (penghasilan netto) wajib pajak dalam keadaan sebagai berikut: 1) Tidak adanya dasar penghitungan lain yang lebih baik, yaitu pembukuan; dan/atau 2) Pem- bukuan Wajib Pajak yang ternyata diselenggarakan tidak benar. Wujud dari Norma Penghitungan itu sendiri ialah berupa suatu prosentase atau angka perbandingan lainnya yang disusun sedemikian rupa berdasarkan hasil penelitian yang cermat sehingga Sederhana; Terperinci menurut kelompok jenis usaha; Dibedakan dalam beberapa klasifikasi kota/tempat; Dibedakan untuk Wajib Pajak yang jumlah peredaran usahanya atau penerimaan brutonya kurang dari Rp. 60.000.000,- dengan yang lebih dari Rp.60.000.000,- (enam puluh juta rupiah); dan Tingkat persentase atau angka perbandingan yang tidak jauh dari kewajaran, namun dapat mendorong Wajib Pajak menyelenggarakan pembukuan. Oleh karena itu, penggunaan Norma Penghitungan dalam menghitung penghasilan netto ini hanya dipergunakan dalam keadaan terpaksa disebabkan karena tidak adanya pegangan atau pedoman untuk menghitung secara jelas namun tetap dapat dipertangung jawabkan.

Selain untuk memberikan kemudahan bagi wajib pajak dalam rangka pemenuhan kewajiban perpajakan, adanya Norma Penghitungan ini dilaksanakan guna mencegah timbulnya tindakan sewenang-wenang Administrasi Perpajakan dengan menaksir besarnya penghasilan yang kurang berdasar. Pihak DJP sebagai pihak yang berwenang untuk membuat serta menerbitkan Norma Penghitungan mempunyai kewajiban untuk menyempurnakan terus menerus Norma Penghitungan ini dengan berdasarkan pedoman atau pegangan yang ditetapkan oleh Menteri Keuangan. Berdasarkan hasil penelusuran tidak menemukan risalah sidang pembentukan Undang-Undang Nomor 7 Tahun 1983 tentang PPh dan Surat Keputusan DIREKTUR JENDERAL PAJAK Nomor KEP-02/PJ.5/1984

tentang Norma Penghitungan Pajak Penghasilan baik penelurusan melalui permohonan pada laman Layanan Informasi Publik Pejabat Pengelola Informasi dan Dokumentasi Sekretariat Jenderal dan Badan Keahlian DPR RI hingga penelusuran melalui internet pada laman lain. Dengan demikian, penelitian ini dengan menggunakan dokumendokumen lain yang telah di dapatkan. 


\section{Jurnal Cakrawala Hukum, Volume 12 No. 2 Agustus 2021}

ISSN PRINT 2356-4962 ISSN ONLINE 2598-6538

Istilah NPPN pertama kali diperkenalkan pada tahun 2000 tepatnya saat diundangkannya Undang-undang Nomor 17 Tahun 2000 tentang perubahan ketiga UU PPh. Menurut pasal 14 ayat (1) undang-undang ini, menjelaskan bahwa "Norma Penghitungan Penghasilan Neto untuk menentukan penghasilan neto, dibuat dan disempurnakan terus-menerus serta diterbitkan oleh Direktur Jenderal Pajak. Bunyi pasal 14 ayat (1) ini masih berlaku hingga sekarang yaitu berdasarkan Undang-undang Nomor 36 Tahun 2008 tentang perubahan keempat UU PPh.

Menurut Direktorat Jenderal Pajak yang diwakili oleh Bapak Diana Wiweko dan Bapak Ichtiar Rachmatullah yang mana dari wawancara tersebut diketahui bahwa terdapat beberapa dasar pertimbangan pengelompokan wilayah pada aturan NPPN sebagaimana diatur pada pasal 4 ayat (1) PER DIRJEN PAJAK Nomor 17/PJ/2015. Menurut Bapak Wiweko, dasar pertimbangan pengelompokkan NPPN tersebut adalah adanya suatu variabel dimana variabel tersebut mempengaruhi penghasilan dari wajib pajak yang bersangkutan. Contoh variabel tersebut antara lain Upah Minimum Regional (UMR), pertumbuhan ekonomi, biaya hidup, jarak dengan sumber bahan baku, dan lain sebagainya. Selaras dengan pernyataan Bapak Wiweko, Bapak Ichtiar juga menyebutkan bahwa dasar pertimbangan pengelompokan NPPN dipengaruhi oleh beberapa faktor sosial dan ekonomi serta perkembangan kota, misalnya Produk Domestik Bruto, pertumbuhan ekonomi daerah, inflasi daerah, demografi wilayah, iklim investasi daerah, termasuk kebijakan publik pemerintah pusat maupun daerah.

Apabila kita melihat kembali aturan pasal 4 ayat (1) PER DIRJEN PAJAK Nomor 17/PJ/2015, kelompok wilayah A dan kelompok wilayah B merupakan daerah yang sama-sama ibu kota provinsi di Indonesia namun dikelompokkan berbeda. Bapak Wiweko menjelaskan bahwa diklasifikasikannya 10 (sepuluh) ibu kota provinsi dalam satu kelompok (kelompok A) dikarenakan pada saat penerbitan PER DIRJEN PAJAK Nomor 17/PJ/2015, 10 (sepuluh) kota pada kelompok A dianggap mewakili kota-kota dengan aktifitas ekonomi yang tinggi dan sebagai pusat kegiatan ekonomi yang cukup strategis di wilayah Indonesia. Berdasarkan penelitian DJP, 10 (sepuluh) kota tersebut memiliki level diatas ibu kota provinsi lainnya dalam hal aktifitas pertumbuhan ekonomi dan sosial serta memiliki demografi wilayah yang mirip. Oleh karena itu, pihak DJP berdasarkan penelitiannya dan pertimbangan-pertimbangan dasar sebagaimana disebutkan diatas mengelompokkan prosentase NPPN berdasarkan wilayah menjadi 3 (tiga) kelompok wilayah.

Secara garis besar PER DIRJEN PAJAK Nomor 17/PJ/2015 tentang NPPN khususnya aturan Pasal 4 ayat (1) mengenai pengelompokkan wilayah NPPN, telah memenuhi aturan penyusunan peraturan perundang-undangan pajak sebagaimana berdasarkan teori The four cannons of Adam Smith atau The Four maxims milik Adam Smith. Dalam teori tersebut, di kemukakan bahwa aturan perpajakan sebaiknya mengandung 4 (empat) asas yang harus dipenuhi agar tercapai rasa keadilan dan kepastian hukum. Keempat asas tersebut antara lain Equality and Equity, Certainty, Convienience of Payment dan Economic of Collection. Berdasarkan teori tersebut, aturan mengenai pengelompokan NPPN berdasarkan wilayah merupakan salah satu perwujudan asas Equality yaitu asas yang diperuntukkan bagi orang-orang dalam kondisi yang sama dimana orang-orang tersebut diberikan perlakuan yang sama karena adanya persamaaan kondisi yang dialami.

Kalimat berada di kondisi yang sama dapat diartikan pula sebagai berada dalam wilayah yang sama dimana variabel penentuan untuk menyamakan kondisi tersebut adalah pertumbuhan ekonomi tiap daerah (pertumbuhan ekonomi regional). Sebagaimana pernyataan Bapak Wiweko dan Bapak Ichtiar, dasar penentuan pengelompokan wilayah NPPN yang paling berpengaruh adalah pertumbuhan ekonomi sosial tiap-tiap daerah. Salah satu 
tolak ukur untuk mengukur tingkat pertumbuhan ekonomi yaitu Produk Domestik Regional Bruto (PDRB) yang merupakan jumlah keseluruhan dari nilai tambah barang dan jasa yang dihasilkan berdasarkan semua kegiatan perekonomian di seluruh wilayah dalam periode tahun tertentu yang pada umumnya dalam kurun waktu satu tahun.

Menurut data Badan Pusat Statistik (BPS) adapun daftar 10 (sepuluh) Provinsi di Indonesia dengan PDRB tertinggi berdasarkan harga konstan pada tahun 2015 antara lain adalah Provinsi DKI Jakarta, Jawa Timur, Jawa Barat, Jawa Tengah, Riau, Sumatera Utara, Kalimantan Timur, Banten, Sumatera Selatan dan Sulawesi Selatan (Databooks, 2010). Sehingga hal ini selaras dengan pernyataan Bapak Wiweko yang menyatakan bahwa dikelompokkannya 10 (sepuluh) ibu kota provinsi pada kelompok wilayah A dikarenakan sepuluh kota tersebut dianggap mewakili kota-kota di Indonesia yang memiliki aktifitas perekonomian yang tinggi serta menjadi pusat kegiatan ekonomi yang cukup strategis di wilayah Indonesia. Dengan demikian dapat kita simpulkan bahwa pengelompokkan NPPN berdasarkan wilayah ini dilatar belakangi oleh adanya asas Equality yaitu asas yang memberikan perlakuan yang sama terhadap orangorang yang berada di wilayah yang sama dimana dasar variabel penentuannya salah satunya adalah pertumbuhan ekonomi regional setiap daerah. dengan tetap memperhatikan nilai-nilai kewajaran lainnya.

\section{Korelasi antara pengelompokkan wilayah berdasarkan PER DIRJEN PAJAK Nomor 17/PJ/2015 dengan pengelompokan kategori daerah kedudukan notaris berdasarkan formasi jabatan notaris yang diatur dalam PERMENKUMHAM Nomor 27/2016}

Tidak hanya dalam aturan perpajakan, dalam aturan kenotariatan juga terdapat pengelompokan wilayah atau lebih sering disebut dengan kategori daerah. Kategori Daerah merupakan pengelompokan tempat kedudukan Notaris yang di dasarkan pada kriteria formasi Jabatan Notaris yang merupakan faktor-faktor yang menentukan jumlah Notaris yang dibutuhkan pada suatu kabupaten atau kota. Notaris dalam melaksanakan tugas jabatan dan kewenangannya berkedudukan di suatu daerah baik kabupaten atau kota yang mana wilayah jabatan Notaris yang bersangkutan meliputi seluruh wilayah provinsi dari kabupaten atau kota kedudukannya. Berdasarkan ketentuan pasal 21 UUJN Formasi Jabatan Notaris ditentukan oleh Menteri yaitu Menteri Hukum dan Hak Asasi Manusia Republik Indonesia sebagai pihak yang berwenang dengan mempertimbangkan usul dari Organisasi Notaris atau Ikatan Notaris Indonesia (INI

Pasal 5 PERMENKUMHAM Nomor 27/2016 telah menentukan bahwa formasi jabatan Notaris ditentukan berdasarkan tiga dasar penentuan, antara lain: Pertama, Unsur penetapan berdasarkan kegiatan usaha yang ditentukan dengan menggunakan data dari perbankan dapat diketahui dari Statistik Perbankan Indonesia (SPI) yang diterbitkan secara periodik (bulanan) oleh Departemen Perizinan dan Informasi Perbankan Otoritas Jasa Keuangan (OJK) untuk memberikan gambaran perkembangan perbankan di Indonesia. Merujuk pengertian dari perbankan itu sendiri sebagaimana dinyatakan dalam undang-undang perbankan, bahwa perbankan merupakan segala sesuatu yang menyangkut tentang bank, mencakup kelembagaan, kegiatan usaha, serta cara dan proses dalam melaksanakan kegiatan usahanya. Oleh karena itu, data dari perbankan yang dimaksud dalam pasal 5 ayat (2) PERMENKUMHAM Nomor 27/2016 dapat merujuk pada data SPI yang diterbitkan oleh OJK dimana dalam SPI tersebut terdapat data statistik dengan beberapa metadata perbankan Indonesia baik dari lingkup Bank umum, Bank Syariah serta Bank Perkreditan Rakyat yang beroperasi di Indonesia. Kedua, Unsur penetapan 


\section{Jurnal Cakrawala Hukum, Volume 12 No. 2 Agustus 2021}

ISSN PRINT 2356-4962 ISSN ONLINE 2598-6538

berdasarkan jumlah penduduk yang dengan menggunakan data dari instansi atau lembaga pemerintah yang mengurusi bidang kependudukan dalam hal ini dapat diketahui dari data sensus penduduk yang dilaksanakan oleh Badan Pusat Statistik Indonesia (BPS). Dengan adanya hasil dari sensus penduduk ini dapat diketahui pula wilayah daerah atau kota dan/atau kabupaten yang memiliki jumlah penduduk dan tingkat kepadatan penduduk yang tertinggi di Indonesia.

Ketiga, Unsur penetapan berdasarkan ratarata jumlah akta yang dibuat oleh dan/atau di hadapan Notaris setiap bulan dengan mengunakan database Direktorat Jenderal Administrasi Hukum Umum (Ditjen AHU). Notaris memiliki kewajiban untuk melaporkan akta-akta yang dibuatnya setiap bulannya kepada Majelis Pengawas Daerah (MPD). Selain kewajiban melaporkan daftar akta kepada MPD, Notaris juga berkewajiban untuk melaporkan daftar akta wasiat secara elektronik melalui laman resmi Ditjen AHU Kemenkumham. Kaitannya dengan melaporkan daftar akta secara elektronik kepada Ditjen AHU Kemenkumham, secara tidak langsung Notaris juga memiliki kewajiban untuk melaporkan akta-akta yang berhubungan dengan Badan Usaha, baik Badan Usaha yang berbadan hukum maupun badan usaha yang tidak berbadan hukum karena saat ini akta-akta yang berkaitan dengan pendirian, perubahan anggaran dasar dan pembubaran Badan Usaha di Indonesia pengesahannya dilakukan oleh Menteri Hukum dan Hak Asasi Manusia melalui pelayanan jasa teknologi informasi secara elektronik yang diselenggarakan oleh Direktorat Jenderal Administrasi Hukum Umum (Ditjen AHU).

Berdasarkan pemaparan hasil analisis diatas, bahwa terdapat korelasi antara pengelompokkan wilayah NPPN yang diatur dalam PER DIRJEN PAJAK Nomor 17/PJ/2015 dengan pengelompokan tempat kedudukan Notaris (kategori daerah) yang di dasarkan pada kriteria formasi Jabatan Notaris yang diatur dalam PERMENKUMHAM Nomor 27/2016. Korelasi tersebut bukan pada jumlah kelompok wilayahnya tetapi lebih berfokus pada faktor dasar penentuan pengelompokan wilayahnya. Pada PER DIRJEN PAJAK Nomor 17/ PJ/2015, pengelompokkan wilayah NPPN dikelompokkan menjadi 3 (tiga) kelompok wilayah sedangkan pada PERMENKUMHAM Nomor 27/2016 mengelompokkan kategori daerah menjadi 4 (empat) kategori daerah, dimana kategori daerah A mengkhususkan Provinsi DKI Jakarta sebagai kategori daerah tersendiri. Secara garis besar, walaupun PERMENKUMHAM Nomor 27/2016 telah menentukan dasar penentuan formasi jabatan Notaris sebagai pedoman menyusun kategori Daerah kedudukan Notaris, namun berdasarkan analisis untuk masing-masing unsur penentu formasi jabatan Notaris tersebut masih ada hubungannya dengan faktor pertumbuhan ekonomi suatu daerah.

NE. Algra menyatakan bahwa pengertian adil tergantung oleh pandangan pribadi seseorang yang mengemukakan tentang keadilan tersebut. Sehingga keadilan merupakan suatu hal yang abstrak dan subjektif. Bahwa adil atau tidaknya suatu aturan hukum tergantung dari sudut pandang mana orang tersebut menilai mengenai suatu keadilan. Selain sudut pandang, latar belakang pendidikan dan kondisi lingkungan masyarakat orang yang menilai tentang keadilan tersebut juga berpengaruh untuk menentukan apakah suatu aturan tersebut telah mencapai keadilan atau belum. Tentunya jika orang yang menilai keadilan tersebut memiliki latar belakang pendidikan akan berpendapat berbeda dengan orang yang tidak memiliki latar belakang. Selain itu kondisi lingkungan masyarakat juga sedikit banyak memberikan pengaruh terhadap opini yang akan disampaikan seseorang yang bependapat mengenai keadilan.

Jika dikaitkan dengan aturan pengelompokan wilayah, dari sudut pandang aturan ini sudah menceriminkan nilai keadilan. Karena jika kita melihat keadilan itu sebagai suatu hal yang mengharuskan seseorang dalam kondisi yang 
sama rata dan sama rasa, maka keadilan tersebut akan susah untuk dicapai. Keadilan yang tepat adalah keadilan yang proporsional dengan tetap memerhatikan hak-hak lainnya agar tidak terjadi kesewenang-wenangan. Aturan mengenai NPPN merupakan aturan alternatif yang diterbitkan oleh Direktorat Jenderal pajak untuk menghindari tindakan kesewenang-wenangan baik oleh wajib pajak maupun oleh pemungut pajak. Selain itu untuk menjamin terciptanya nilai keadilan, maka DJP mengatur mengenai pengelompokkan wilayah NPPN untuk menentukan besaran persentase yang akan digunakan nantinya. Pengelompokkan wilayah ini di dasarkan pada PDRB dimana kota atau kabupaten yang memiliki PDRB tinggi dikelompokkan menjadi satu. Aturan mengenai daerah yang memiliki PDRB tinggi ini tentunya harus diperlakukan berbeda dengan daerah yang memiliki PDRB rendah. Dengan demikian, antara daerah yang memiliki PDRB rendah ini tetap merasakan nilai keadilan karena pengaturannya di samakan dengan kondisi yang sama dengan daerah yang bersangkutan.

Kemudian untuk pengelompokan kategori daerah kedudukan Notaris, adapun pengaturan mengenai pengelompokkan daerah ini bertujuan juga untuk pemerataan Notaris di Indonesia. Pemerataan dalam rangka penyebaran pelayanan jasa hukum oleh Notaris di seluruh Indonesia dapat diartikan sebagai salah satu bentuk untuk mewujudkan nilai keadilan baik bagi Notaris maupun bagi masyarakat Indonesia. Diharapkan dengan adanya kategori daerah ini calon-calon Notaris dapat memilih tempat kedudukan tidak hanya pada Kota atau Kabupaten yang besar saja, namun juga pada daerah yang jumlah Notarisnya masih sedikit. Sehingga pelayanan jasa hukum Notaris dapat merata di seluruh wilayah Kota maupun Kabupaten di Indonesia.

Dengan demikian, aturan pengelompokkan wilayah pada PER DIRJEN PAJAK Nomor 17/PJ/ 2015 dan PERMENKUMHAM Nomor 27/2016 telah memenuhi nilai keadilan sebagaimana teori keadilan yang dikemukakan oleh Aristoteles yang melihat keadilan dari apa yang terjadi pada sesuatu yang berada dalam kondisi yang sama. Memiliki kondisi yang sama dapat diartikan pula sebagai memiliki kondisi atau karakteristik daerah yang sama berdasarkan variabel tertentu sehingga dikelompokkan menjadi satu kelompok. Sebelum mengelompokkan wilayah-wilayah tersebut, tentunya pihak yang berwenang baik Direktorat Jenderal Pajak maupun Kementerian Hukum dan Hak Asasi Manusia telah menyelenggarakan suatu penelitian terlebih dahulu dan menentukan variabel pengukurnya yang salah satu variabel pengukurnya adalah pertumbuhan ekonomi disetiap daerah yang bersangkutan. Dengan dilakukannya penelitian terlebih dahulu sebelum menentukan kelompok-kelompok wilayah maka diketahui bahwa pengelompokan wilayah ini tidak serta merta dilakukan oleh pihak pembuat undangundang.

Pengelompokan wilayah ini bukan tindakan diskriminatif yang membeda-bedakan daerah di Indonesia tanpa ada alasan yang jelas dan berdasar sehingga tidak mencerminkan nilai-nilai keadilan. Pengelompokan wilayah dilakukan sebagai salah satu wujud keadilan secara distributif dimana Negara memberikan keadilan atas hak warga negaranya dimana hak itu haruslah sama diantara orang-orang yang sama (dalam kondisi atau wilayah yang sama). Selain itu, dengan adanya pengelompokan wilayah ini diharapkan tercapainya suatu pemerataan pembangunan di Indonesia agar tujuan Negara Indonesia dalam hal memajukan kesejahteraan umum dan keadilan sosial dapat tercapai.

\section{Simpulan}

Pengelompokan NPPN berdasarkan wilayah merupakan salah satu perwujudan asas Equality dalam peraturan perpajakan yaitu asas yang memberikan perlakuan yang sama terhadap orangorang yang berada di kondisi yang sama dimana 


\section{Jurnal Cakrawala Hukum, Volume 12 No. 2 Agustus 2021}

ISSN PRINT 2356-4962 ISSN ONLINE 2598-6538

kalimat berada di kondisi yang sama dapat diartikan pula sebagai berada dalam karakteristik wilayah yang sama. Adapun yang menjadi dasar pertimbangan pengelompokkan wilayah tersebut didasarkan pada beberapa variabel antara lain letak wilayah, pertumbuhan ekonomi regional, UMR, biaya hidup, dan sebagainya.

Formasi Jabatan Notaris merupakan pedoman untuk menentukan Kategori Daerah Kedudukan Notaris yang ditetapkan berdasarkan tiga dasar penetepan dimana penetapan-penetapan tersebut erat hubungannya dengan kegiatan ekonomi dalam suatu daerah sehingga secara garis besar korelasi pengelompokan wilayah antara kedua aturan tersebut terletak pada faktor dasar penentuan pengelompokan wilayahnya yaitu pertumbuhan ekonomi tiap daerah (pertumbuhan ekonomi regional). Pengelompokan wilayah baik berdasarkan aturan perpajakan maupun aturan kenotariatan telah memenuhi nilai keadilan karena memiliki kondisi yang sama dapat diartikan pula sebagai memiliki kondisi atau karakteristik daerah yang sama berdasarkan variabel tertentu sehingga dikelompokkan menjadi satu kelompok. Selain itu, aturan pengelompokan wilayah ini terlebih dahulu dilakukan penelitian oleh masing-masing pihak yang berwenang sehingga pengelompokkan wilayah ini memiliki dasar yang jelas dan tegas dan bukanlah tindakan diskriminatif pembuat undang-undang (Pemerintah) kepada masyarakatnya.

\section{Daftar pustaka}

Adjie, Habib. 2008. Hukum Notaris Indonesia, Tafsir tematik terhadap Undang-Undang No. 30 Tahun 2004 tentang Jabatan Notaris. Bandung: Refika Aditama.
Aruan, Albert R. 2020. Panduan Perpajakan Notaris \& PPAT. Jakarta: Tax Visory Media.

Dwisvimiar, Inge. 2011. Keadilan Dalam Perspektif Filsafat Ilmu Hukum. Jurnal Dinamika Hukum, Vol. 11 No. 3 September 2011. Universitas Sultan Ageng Tirtayasa.

Edwar, dkk, Kedudukan Notaris sebagai Pejabat Umum Ditinjau dari Konsep Equality Before the Law. Jurnal Hukum \& Pembangunan, 49 No. 1. Universitas Indonesia.

Nasution, Bahder Johan. 2014. Kajian Filosofis tentang Konsep Keadilan dari Pemikiran Klasik Sampai Pemikiran Modern. Jurnal Yustisia, Vol. 3 No 2 Mei - Agustus 2014. Universitas Jambi.

Negara, Tunggul Anshari Setia. 2005. Pengantar Hukum Pajak. Malang: Bayu Media.

Peraturan Direktur Jenderal Pajak Nomor PER-17/PJ/ 2015 tentang Norma Penghitungan Penghasilan Neto.

Peraturan Menteri Hukum dan Hak Asasi Manusia Republik Indonesia Nomor 27 Tahun 2016 tentang Formasi Jabatan Notaris dan Penentuan Kategori Daerah.

Pratiwi, RO. (2020). Perlindungan hukum bagi penerima wasiat terhadap notaris yang tidak melaporkan akta wasiat secara elektronik. Jurnal Cakrawala Hukum. 11(3). 333-340. doi:10.26905/ idjch.v11i3.4267.

Undang-Undang Nomor 30 Tahun 2004 tentang Jabatan Notaris.

Undang-Undang Nomor 6 Tahun 1983 tentang Ketentuan Umum dan Tata Cara Perpajakan.

Undang-Undang Nomor 7 Tahun 1983 tentang Pajak Penghasilan.

Wirawan, B. Ilyas, dkk. 2011. Hukum Pajak Material 1 Seri Pajak Penghasilan. Jakarta: Salemba Humanika. 